\title{
KEPATUHAN PERAWAT MELAKSANAKAN STANDAR PROSEDUR OPERASIONAL PENCEGAHAN PASIEN JATUH BERDASARKAN FAKTOR DEMOGRAFI DAN MOTIVASI
}

Nurses Implementing Compliance Standard Operating Procedure For The Prevention Of Fall Patients On Based of The Demographic Factors And Motivations

\author{
Ni Panjawi Lacshita Jati ${ }^{1}$
}

${ }^{1}$ Fakultas Kesehatan Masyarakat Universitas Airlangga, 1

\begin{abstract}
Implementation of patient safety such as reducing the patient fall risk, needs various Standard Operating Procedures (SOPs) and guidelines. However, based on former research there were nurses did not implement the SOP of early assessment by $60 \%$ and 100\% of reassessment in 2016 at Hospital X Surabaya. The objectives of the study were to analyze the compliance of the implementation of the SOP of Prevention Patient Falls include SOP of Assessment and Reassessment Patient Falls Risk and SOP of Sticking Stickers to Patient Falls Risk in Hospital X Surabaya based on motivation factor. The research type was analytic (observasional approach) used cross sectional design. The sample of research was 47 nurses. The dependent variable of research was the compliance of nurses in implementing of the SOP of Prevention Patient Falls. The independent variable of research were the motivation factor. Data were analyzed using Crosstab. Results of the research is said that the higher the motivation, the higher the compliance of nurses in implementing of the SPO of Prevention Patients Fall. Then, there was relationship between the compliance of implementation of Standard Operating Procedures (SOPs) of Patient Fall Prevention with motivation. The suggested for hospital to socialization, increase nurses motivation, give appreciation, give exercise and commitment of implementation of the SOP of Prevention Patient Falls.

Keywords: Motivation factor, Compliance of nurses, The SOP of Patient Falls Prevention
\end{abstract}




\begin{abstract}
ABSTRAK
Penyelenggaraan keselamatan pasien seperti mengurangi pasien risiko jatuh memerlukan berbagai Standar Prosedur Operasional (SPO) dan panduan pelaksanaannya. Namun, berdasarkan penelitian sebelumnya terdapat perawat yang tidak melaksanakan SPO assesmen awal sebesar 60\% dan 100\% assemen ulang pada tahun 2016 di Rumah Sakit X Surabaya. Penelitian ini dilakukan untuk menganalisis kepatuhan perawat melaksanakan SPO Pencegahan Pasien Jatuh yang terdiri dari SPO Assessmen dan Assesmen Ulang Pasien Resiko Jatuh dan SPO Pemasangan Stiker Pasien Resiko Jatuh di Rumah Sakit X Surabaya berdasarkan faktor motivasi. Jenis penelitian adalah analitik dengan pendekatan observasional dan menggunakan rancang bangun cross sectional. Kuesioner disebarkan kepada 47 perawat. Variabel dependen penelitian adalah kepatuhan perawat dalam melaksanakan SPO Pencegahan Pasien Jatuh. Variabel independen penelitian adalah faktor motivasi. Data dianalisis menggunakan tabulasi silang. Analisis menunjukkan semakin tinggi motivasi perawat, maka semakin tinggi pula kepatuhan perawat dalam melaksanakan SPO Pencegahan Pasien Jatuh. Selain itu, terdapat hubungan signifikan antara kepatuhan dengan faktor motivasi. Disarankan bagi pihak rumah sakit untuk mengadakan sosialisasi, meningktakan motivasi perawat, memberikan apresiasi, pelatihan dan komitmen dalam pelaksanaan SPO Pencegahan Pasien Jatuh.
\end{abstract}

Kata Kunci: Faktor motivasi, kepatuhan perawat, SPO Pencegahan Pasien Jatuh

\section{PENDAHULUAN}

Rumah Sakit merupakan salah satu sarana pelayanan kesehatan yang bertujuan untuk pemulihan dan pemeliharaan kesehatan yang lebih baik. Pada era global seperti saat ini pelayanan sudah tidak lagi hanya berfokus pada kepuasan pasien tetapi lebih pada keselamatan pasien (patient safety). Harapan pelayanan profesional yang bermutu adalah pelayanan yang berfokus pada keselamatan (safety) dan kepuasan pasien dapat terlaksana dengan baik. Peraturan Menteri Kesehatan Republik Indonesia nomor 1691 tahun 2011 tentang Keselamatan Pasien Rumah Sakit bahwa Insiden keselamatan pasien yang selanjutnya disebut insiden adalah setiap kejadian yang tidak disengaja dan kondisi yang mengakibatkan atau berpotensi mengakibatkan cedera yang dapat dicegah pada pasien, dan terdiri dari Kejadian Tidak Diharapkan, Kejadian Nyaris Cedera, Kejadian Tidak Cedera dan Kejadian Potensial Cedera.

Setiap rumah sakit wajib untuk memenuhi sasaran keselamatan pasien. Salah satu sasaran keselamatan pasien rumah sakit adalah mengurangi risiko pasien jatuh. Menurut Tinetti dan Speechley (1989) dalam Lorraine tahun 2012 menyatakan bahwa pasien jatuh didefinisikan sebagai tiba-tiba, perubahan yang tidak disengaja dalam posisi, jatuh di lantai atau tingkat yang lebih rendah lainnya, adalah salah satu kejadian insiden yang paling sering dilaporkan rumah sakit yang tentunya merugikan bagi rumah sakit dengan lebih dari satu juta per tahun terjadi. Pelaksanaan pengurangan risiko pasien jatuh diperlukan berbagai Standar Prosedur Operasional (SPO) salah satunya pelaksanaan SPO Pencegahan Pasien Jatuh adalah SPO Assessmen dan Assesmen Ulang serta SPO Pemasangan Stiker Pasien Risiko Jatuh.

Berdasarkan studi pendahuluan berupa observasi rekam medis pasien rawat inap yang dilaksanakan pada tanggal 14 hingga tanggal 15 April 2016 di Rumah Sakit X Surabaya. Hal ini dimaksudkan untuk melihat kepatuhan perawat dalam melaksanakan SPO Pencegahan Pasien Jatuh di Rumah Sakit X Surabaya. Berdasarkan dari 10 rekam medis, terdapat 6 (enam) pasien atau 60\% yang tidak dilakukan assesmen awal dan $100 \%$ pasien yang memiliki risiko jatuh tidak dilakukan pengkajian ulang risiko jatuh oleh perawat. Hal ini ditunjukkan pada form pengkajian ulang pasien risiko jatuh yang masih kosong, sehingga menyebabkan 
dokumentasi dan implementasi form pengkajian pasien risiko jatuh menjadi tidak lengkap. Penelitian ini bertujuan untuk menganalisis kepatuhan perawat melaksanakan SPO Pencegahan Pasien Jatuh berdasarkan faktor demografi dan motivasi. Hasil penelitian diharapakan dapat menggambarkan kinerja perawat dan memabantu untuk mencegah maupun menurunkan Kejadian yang Tidak Diharapkan (KTD) khususnya pada sasaran pasien resiko jatuh di Rumah sakit $\mathrm{X}$ Surabaya.

\section{METODE PENELITIAN}

Penelitian ini adalah analitik dengan pendekatan observasional dan rancang bangun cross sectional. Populasi adalah semua perawat di Rumah Sakit X Surabaya. Sampel penelitian yaitu semua perawat yang memenuhi kriteria inklusi dan eksklusi sejumlah 47 perawat. Kriteria inklusi dalah perawat yang memiliki kewenangan untuk melakukan assesmen dan assesmen ulang pasien resiko jatuh; melaksanakan pekerjaannya di Rumah Sakit X Surabaya; dan bersedia menjadi responden penelitian, sedangkan kriteria eksklusi adalah perawat yang tidak memiliki kewenangan untuk melakukan assesmen dan assesmen ulang pasien resiko jatuh; tidak melaksanakan pekerjaannya di Rumah Sakit X Surabaya; dan menjabat sebagai supervisor. Penelitian dilakukan di Unit Rawat Inap Rumah Sakit $X$ yang terletak di Kota Surabaya. Waktu penelitian dilaksanakan dari bulan November 2015 hingga Juni 2016.

Variabel dependen penelitian adalah kepatuhan perawat melaksanakan Standar Prosedur Pencegahan Pasien dan variabel independen adalah faktor demografi dan motivasi. Pengumpulan data primer didapatkan melalui penyebaran kuesioner yang telah diuji validitas dan reabilitas. Kemudian, data diolah dan dianalisis secara univariabel dan bivariabel. Tujuan analisis univariabel adalah untuk menghitung distribusi frekuensi pada variabel dependen dan independen, sedangkan analsisis bivariabel untuk melakukan analisis menggunakan tabulasi silang (Crosstab).
Apabila terdapat perbedaan persentase $>20 \%$ pada hasil kategori, maka dikatakan terdapat hubungan antara variabel independen dengan variabel dependen, sebaliknya jika perbedaan persentase $\leq 20 \%$ pada hasil kategori, maka dikatakan tidak ada hubungan antara variabel independen dengan variabel dependen.

\section{HASIL PENELITIAN DAN PEMBAHASAN}

$\begin{array}{lcr}\text { Gambaran } & \text { Perawat } & \text { Menurut } \\ \text { Karakteristik } & \begin{array}{c}\text { Demografi, } \\ \text { Tingkat }\end{array} \\ \text { Kepatuhan, dan Tingkat Motivasi }\end{array}$

Berdasarkan pada karakteristik demografi perawat pada tabel 1 menunjukkan bahwa mayoritas perawat di Rumah Sakit X berusia 20-40 tahun (91,5\%). Mayoritas perawat berjenis kelamin perempuan sebanyak 37 perawat (78,7\%). Menurut status perkawinan mayoritas perawat berstatus telah menikah sejumlah 37 perawat $(78,7 \%)$. Berdasarkan pada tingkat pendidikan terakhir mayoritas perawat berpendidikan D3 sejumlah 37 perawat $(78,7 \%)$. Menurut lama masa kerja berada pada kategori tinggi sebanyak 24 perawat $(51,1 \%)$. Lama masa kerja tersebut dikategorikan menjadi dua yaitu rendah dan tinggi berdasarkan pada rata-rata lama masa kerja perawat yang menjadi responden yaitu 40,15 bulan atau sekitar 3 tahun.

Kemudian, menurut hasil penelitian dilakukan terhadap 47 perawat di Rumah Sakit X Surabaya terdapat 26 perawat $(55,3 \%)$ yang memiliki kepatuhan rendah dan 21 perawat $(44,7 \%)$ memiliki kepatuhan tinggi dalam melaksanakan Standar Prosedur Operasional (SPO) Pencegahan Pasien Jatuh. Responden yang memiliki jumlah nilai kurang dari nilai ratarata jawaban yaitu 33,6 maka dikelompokkan sebagai perilaku yang memiliki kepatuhan rendah, sebaliknya jika jumlah jawaban sama atau diatas nilai ratarata jawaban maka perawat dikelompokkan menjadi perilaku yang memiliki kepatuhan tinggi. Demikian, perawat yang tidak melaksanakan SPO Pencegahan Pasien Jatuhlebih banyak jumlanya daripada yang melaksanakan. 
Motivasi pada penelitian ini dibedakan menjadi dua kategori yaitu rendah dan tinggi berdasarkan nilai rata-rata dari responden yaitu 12,51. Tingkat motivasi dari 47 perawat terdapat 32 perawat $(68,1 \%)$ yang memiliki motivasi rendah dalam melaksanakan Standar Prosedur Operasional (SPO) Pencegahan Pasien Jatuh. Kemudian, terdapat 15 perawat $(31,9 \%)$ yang memiliki tingkat motivasi tinggi dalam melaksanakan Standar Prosedur Operasional (SPO) Pencegahan Pasien Jatuh. hasil ini menunjukkan bahwa motivasi perawat di Rumah Sakit $X$ Surabaya masih tergolong rendah dalam melaksanakan SPO Pencegahan Pasien Jatuh.

Tabel 1. Distribusi Perawat Menurut Karakteristik Demografi, Tingkat Motivasi, dan Tingkat Kepatuhan

\begin{tabular}{lll} 
Variabel & $\mathrm{n}$ & Persentase \\
\hline Usia & & \\
20-40 tahun & 43 & 91,5 \\
$>40$ tahun & 4 & 8,5 \\
\hline Jenis Kelamin & & \\
Laki-laki & 10 & 21,3 \\
Perempuan & 37 & 78,7 \\
\hline Status Pernikahan & & \\
Belum menikah & 10 & 21,3 \\
Menikah & 37 & 78,7 \\
\hline Tingkat Pendidikan & & \\
SPK & 0 & 0 \\
D3 & 37 & 78,7 \\
S1 & 10 & 21,3 \\
S2 & 0 & 0 \\
\hline Lama Masa Kerja & & \\
Rendah & 23 & 48,9 \\
Tinggi & 24 & 51,1 \\
\hline Tingkat Motivasi & & \\
Rendah (12,51) & 32 & 68,1 \\
Tinggi (12,51) & 15 & 31,9 \\
\hline Tingkat Kepatuhan & & 55,3 \\
Rendah (<33,6) & 26 & 44,7 \\
Tinggi ( $\geq 33,6)$ & 21 & \\
\hline & & \\
\hline
\end{tabular}

\section{Analisis Kepatuhan Perawat Melaksanakan Standar Prosedur Operasional (SPO) Pencegahan Pasien Jatuh Berdasarkan Faktor Demografi}

Responden dalam penelitian ini dikategorikan berdasarkan usia yang produktif dan angkatan kerja yaitu kelompok umur dewasa muda yaitu 20-40 tahun dan dewasa madia yaitu 40-65 tahun (Robbins, 2006). Pada tabel 2 dapat dipelajari bahwa kelompok usia dewasa madia yiatu 40-60 tahun cenderung lebih patuh dalam melaksanakan SPO Pencegahan Pasien Jatuh daripada kelompok usia muda. Hasil tabulasi silang menunjukkan bahwa pada usia 20-40 tahun memiliki tingkat kepatuhan tinggi sebesar $41,9 \%$, sedangkan pada usia lebih dari 40 tahun memiliki tingkat kepatuhan tinggi sebesar $75 \%$. Berdasarkan pada perbedaan kedua persentase yang lebih dari $20 \%$, maka dapat disimpulkan bahwa terdapat hubungan signifikan antara usia perawat dengan kepatuhan pelaksanaan Standar Prosedur Operasional (SPO) Pencegahan Pasien Jatuh di Rumah Sakit X Surabaya tahun 2016.

Perawat dengan jenis kelamin perempuan cenderung lebih patuh daripada perawat dengan jenis kelamin laki-laki. Hasil tabulasi silang menunjukkan bahwa perawat berjenis kelamin laki-laki memiliki kepatuhan tinggi sebesar 30\%, sedangkan pada perawat perempuan yang memiliki kepatuhan tinggi sebesar 48,6\%. Berdasarkan pada perbedaan kedua persentase yang tidak melebihi dari $20 \%$, maka dapat disimpulkan bahwa tidak terdapat hubungan signifikan antara jenis kelamin perawat dengan kepatuhan terhadap pelaksanaan Standar Prosedur Operasional (SPO) Pencegahan Pasien Jatuh di Rumah Sakit X Surabaya tahun 2016.

Perawat dengan status telah menikah cenderung lebih patuh dalam melaksanakan SPO Pencegahan Pasien Jatuh daripada perawat yang belum menikah. Hasil tabulasi silang menunjukkan perawat yang belum menikah dan memiliki kepatuhan tinggi sebesar 30\%, sedangkan pada 
perawat yang telah menikah dan memiliki kepatuhan tinggi sebesar 48,6\%. Berdasarkan pada perbedaan kedua persentase yang tidak melebihi dari $20 \%$, maka dapat disimpulkan bahwa tidak terdapat hubungan signifikan antara status perkawinan perawat dengan kepatuhan terhadap pelaksanaan Standar Prosedur Operasional (SPO) Pencegahan Pasien Jatuh di Rumah Sakit X Surabaya tahun 2016.

Berdasarkan pada tabel 2 dapat dipelajari bahwa semakin tinggi jenjang pendidikan perawat maka semakin rendah kepatuhan perawat dalam melaksanakan SPO Pencegahan Pasien Jatuh. Hasil tabulasi silang menunjukkan perawat yang berpendidikan D3 memiliki kepatuhan tinggi sebesar 45,9\%, sedangkan pada perawat yang telah menikah dan memiliki kepatuhan tinggi sebesar 40,0\%. Berdasarkan pada perbedaan kedua persentase yang tidak melebihi dari $20 \%$, maka dapat disimpulkan bahwa tidak terdapat hubungan signifikan antara tingkat pendidikan perawat dengan kepatuhan terhadap pelaksanaan Standar Prosedur Operasional (SPO) Pencegahan Pasien Jatuh di Rumah Sakit X Surabaya tahun 2016.

Kemudian, pada tabel 2 dapat kita pelajari bahwa semakin tinggi lama masa kerja perawat maka semakin tinggi pula tingkat kepatuhan perawat dalam melaksanakan SPO Pencegahan Pasien Jatuh. Hasil tabulasi silang menunjukkan perawat dengan lama masa kerja rendah yang memiliki kepatuhan tinggi sebesar 43,5\%, sedangkan pada perawat dengan lama masa kerja tinggi yang memiliki kepatuhan tinggi sebesar 45,8\%. Berdasarkan pada perbedaan kedua persentase yang tidak melebihi dari $20 \%$, maka dapat disimpulkan bahwa tidak terdapat hubungan signifikan antara lama masa kerja perawat dengan kepatuhan terhadap pelaksanaan Standar Prosedur Operasional (SPO) Pencegahan Pasien Jatuh di Rumah Sakit X Surabaya tahun 2016.

Tabel 2. Analsis Tabulasi Silang Faktor Demografi dengan Kepatuhan Pelaksanaan SPO Pencegahan
Pasien Jatuh di Rumahsakit X

Surabaya Tahun 2016

\begin{tabular}{llll}
\hline Variabel & \multicolumn{3}{l}{$\begin{array}{l}\text { Kepatuhan SPO } \\
\text { Pencegahan Pasien Jatuh }\end{array}$} \\
\cline { 2 - 5 } & \multicolumn{4}{l}{ Rendah } & \multicolumn{2}{c}{ Tinggi } \\
\hline n & $\%$ & n & $\%$
\end{tabular}

Usia

\begin{tabular}{lllll}
\hline $20-40$ tahun & 25 & 58,1 & 18 & $\mathbf{4 1 , 9}$ \\
$>40$ tahun & 1 & 25,0 & 3 & $\mathbf{7 5 , 0}$
\end{tabular}

Jenis Kelamin

\begin{tabular}{lcccc}
\hline Laki-laki & 7 & 70,0 & 3 & $\mathbf{3 0 , 0}$ \\
Perempuan & 19 & 51,4 & 18 & $\mathbf{4 8 , 6}$
\end{tabular}

Status Perkawinan

\begin{tabular}{lrrrr}
\hline Belum Menikah & 7 & 70,0 & 3 & $\mathbf{3 0 , 0}$ \\
Menikah & 19 & 51,4 & 18 & $\mathbf{4 8 , 6}$ \\
& & & & \\
\hline Tingkat Pendidikan & & & & \\
\hline D3 & 6 & 60,1 & 17 & $\mathbf{4 5 , 9}$ \\
S1 & & & & $\mathbf{4 0 , 0}$ \\
\hline Lama Masa Kerja & 13 & 56,5 & 10 & $\mathbf{4 3 , 5}$ \\
Rendah & 13 & 54,2 & 11 & $\mathbf{4 5 , 8}$ \\
Tinggi & & & & \\
\hline
\end{tabular}

Analisis Kepatuhan r Perawat
Melaksanakan Standar Prosedur
Operasional (SPO) Pencegahan Pasien
Jatuh Berdasarkan Faktor Motivasi

Berdasarkan pada tabel 2 dapat dipelajari bahwa semakin tinggi motivasi maka semakin tinggi pula kepatuhan perawat dalam melaksanakan SPO Pencegahan Pasien Jatuh. Hasil tabulasi silang menunjukkan perawat dengan motivasi rendah yang memiliki kepatuhan tinggi sebesar $37,5 \%$, sedangkan pada perawat dengan motivasi tinggi yang memiliki kepatuhan tinggi sebesar 60,0\%. Berdasarkan pada perbedaan kedua persentase yang melebihi dari $20 \%$, maka dapat disimpulkan bahwa terdapat hubungan signifikan antara motivasi perawat dengan kepatuhan terhadap pelaksanaan Standar Prosedur Operasional (SPO) Pencegahan Pasien Jatuh di Rumah Sakit X Surabaya tahun 2016. 
Tabel 3. Distribusi Responden Berdasarkan Tingkat Kepatuhan dan Motivasi Pelaksanakan SPO Pencegahan Pasien Jatuh di Rumah Sakit X Surabaya Tahun 2016

\begin{tabular}{llllr}
\hline Variabel & \multicolumn{3}{l}{$\begin{array}{l}\text { Kepatuhan SPO } \\
\text { Pencegahan Pasien } \\
\text { Jatuh }\end{array}$} \\
\cline { 2 - 6 } & Rendah & \multicolumn{2}{l}{ Tinggi } \\
\cline { 2 - 6 } & $\mathbf{n}$ & $\mathbf{\%}$ & $\mathbf{n}$ & $\mathbf{\%}$ \\
\hline Motivasi & 20 & 62,5 & 12 & $\begin{array}{r}\mathbf{3 7} \\
\mathbf{5}\end{array}$ \\
Rendah & 6 & 40,0 & 9 & $\begin{array}{r}\mathbf{6 0} \\
\mathbf{0}\end{array}$ \\
\hline Tinggi & & & & \\
\hline
\end{tabular}

PEMBAHASAN

Faktor demografi individu responden terdiri dari usia, jenis kelamin, status perkawinan, pendidikan, dan lama masa kerja. Berikut merupakan pembahasan dari masing-masing variabel. Pada hasil penelitian dikemukakan bahwa kelompok usia dewasa madia yiatu 40-60 tahun cenderung lebih patuh dalam melaksanakan SPO Pencegahan Pasien Jatuh daripada kelompok usia muda.Hasil penelitian ini sesuai dengan pendapat Robbins (2006) yang menyatakan bahwa semakin tinggi usia juga dapat terlihat semakin berpengalaman, etika kerja yang tinggi, matang dalam mengambil keputusan, toleransi terhadap pandangan orang lain, berpikir secara rasional dan komitmen terhadap pencapaian mutu.

Kemudian, didukung oleh Robbins (2006) dimana usia dewasa madia (40-65 tahun), merupakan tahap puncak dari perkembangan kemampuan mental dasar. Seseorang yang berada pada tahap dewasa madia merupakan seseorang yang ahli dan memiliki keterampilan yang tinggi dalam memecahkan masalah. Walaupun, pada tahap ini seseorang tersebut mengalami penuruan kreativitas tetapi kualitas kognitifnya semakin meningkat.Usia juga menentukan kemampuan seseorang untuk bekerja, termasuk bagaimana merespon stimulasi (Sopiah, 2008).
Berdasarkan hasil analisis tabulasi silang hubungan menunjukkan bahwa terdapat hubungan yang signifikan antara usia dengan kepatuhan perawat dalam pelaksanaan SPO Pencegahan Pasien Jatuh. Hal ini tidak sesuai dengan penelitian yang dilakukan oleh Hikmah (2008) yang menyatakan bahwa tidak ada hubungan antara usia dengan presepsi perawat terhadap staf mengenai patient safety.

Pada hasil penelitian bahwa jumlah perawat dengan jenis kelamin perempuan sebanyak 37 orang $(78,7 \%)$ menjadi mayoritas dibandingkan dengan perawat yang berjenis kelamin laki-laki. Hasil penelitian inimemiliki kesamaan dengan teori yangdikemukakan bahwa jenis kelamin perawatdidominasi oleh perempuan, karena dalamsejarahnya keperawatan muncul sebagaiperan care taking (pemberi perawatan)secara tradisional di dalam keluarga danmasyarakat (Rolinson dan Kish, 2010).

Hasil penelitian menunjukkan bahwa perawat dengan jenis kelamin perempuan cenderung lebih patuh daripada perawat dengan jenis kelamin laki-laki. Hasil ini sesuai dengan Robbins dan Judge(2006) bahwa perempuan lebih patuh dalam menjalankan wewenangnya daripada laki-laki. Hal ini dikarenakan, laki-laki memiliki sifat agresif dan sebuah pengharapan untuk sukses. Walaupun demikian, perbedaan tersebut sangat kecil. Laki-laki dan perempuan tidak ada perbedaan dalam melakukan pemecahan masalah, keterampilan analitis, motivasi, sosialitas dan lain sebagainya. Menurut Sopiah (2008) bahwa karyawan perempuan cenderung lebih rajin dalam bekerja.

Berdasarkan tabulasi silang hubungan antara jenis kelamin perawat dengan kepatuhan terhadap pelaksanaan Standar Prosedur Operasional (SPO) Pencegahan Pasien Jatuh di Rumah Sakit X Surabaya tahun 2016 dikatakan bahwa tidak terdapat hubungan yang signifikan. Hasil penelitian ini sesuai dengan yang dilakukan oleh Handayani, Meliana tahun 2014 bahwa tidak ada hubungan antara variabel jenis kelamin dengan kepatuhan perawat 
pelaksana dalam melaksanakan program patient safety.

Penelitian ini menunjukkan bahwa perawat dengan status telah menikah cenderung lebih patuh dalam melaksanakan SPO Pencegahan Pasien Jatuh daripada perawat yang belum menikah. Hasil penelitian ini sesuai menurut Robbins dan Judge (2008) yang menyatakan bahwa status perkawinan seseorang dapat memiliki hubungan dalam perilaku seseorang di kehidupan berorganisasinya. Karyawan yang telah menikah biasanya memiliki sedikit absen kerja, lebih puas dengan hasil kerjanya, dan rendah mengalami pergantian kerja. Menurut Sopiah (2008) bahwa karyawan yang sudah menikah akan lebih memaknai sebuah pekerjaan dibandingkan dengan karyawan yang belum menikah

Hasil tabulasi silang menunjukkan bahwa tidak ada hubungan antara status pernikahan denga kepatuhan perwat dalam pelaksanaan SPO Pencegahan Pasien Jatuh di Rumah Sakit X Surabaya. Hasil penelitian ini sesuai dengan yang dilakukan oleh Handayani, Meliana (2014) bahwa tidak ada hubungan antara variabel jenis kelamin dengan kepatuhan perawat pelaksana dalam melaksanakan program patient safety. Anugrahini (2010) juga mendukung hasil penelitian ini dengan menyatakan bahwa tidak ada hubungan antara status pernikahan dengan kepatuhan perawat dalam menerapkan pedoman patient safety.

Penelitian ini menujukkan bahwa sebagian besar perawat yang berkerja di Rumah Sakit X Surabaya berpendidikan D3 sebanyak 37 orang $(78,7 \%)$. Standar pendidikan keperawatan Indonesia adalah lulusan pendidikan tinggi keperawatan minimal DIII Keperawatan (Undang-undang No. 20 tahun 2003 tentang Sistem Pendidikan Nasional). Selain itu, dikemukakan bahwa semakin tinggi jenjang pendidikan perawat maka semakin rendah kepatuhan perawat dalam melaksanakan SPO Pencegahan Pasien Jatuh. Hal ini tidak sesuai dengan Niven (2008) yang menyatakan bahwa pendidikan adalah sebuah usaha secara sadar dan direncanakan dalam menciptakan suasana belajar dan proses pembelajaran yang dapat mengembangkan potensi dirinya secara aktif.

Berdasarkan hasil tabulasi silang ditemukan bahwa tidak terdapat hubungan signifikan antara tingkat pendidikan perawat dengan kepatuhan terhadap pelaksanaan Standar Prosedur Operasional (SPO) Pencegahan Pasien Jatuh di Rumah Sakit X Surabaya tahun 2016. Hasil penelitian ini sesuai dengan penelitian Hikmah (2008) yang mengatakan bahwa tidak ada hubungan antara tingkat pendidikan dengan persepsi perawat dalam menerapkan pedoman patient safety. Selain itu, penelitian Handayani, Meliana (2014) menyatakan bahwa tidak ada hubungan antara latar belakang pendidikan perawat dengan kepatuhan perawat dalam melaksanakan pedoman patient safety di Rumah Sakit Stella Maris Makassar. Penelitian ini berbeda dengan pendapat Anugrahini (2010) yang mengatakan bahwa latar belakang pendidikan mempengaruhi kepatuhan perawat dalam menerapkan pedoman patient safety.

Penelitian ini menunjukkan bahwa semakin tinggi lama masa kerja perawat maka semakin tinggi pula tingkat kepatuhan perawat dalam melaksanakan SPO Pencegahan Pasien Jatuh. Hasil penelitian ini sesuai dengan Ranupendoyo dan Saud (2005), yang menyatakan semakin lama seseorang bekerja di suatu organisasi, maka orang tersebut juga akan semakin berpengalaman sehingga cakap dalam bekerja. Menurut Arfianti (2010), dikatakan bahwa pengalaman kerja yang baik akan membuat seseorang semakin sadar dan bertindak sesuai dengan Standar Prosedur Operasional (SPO).

Pada hasil tabulasi silang dikatakan bahwa tidak terdapat hubungan signifikan antara lama masa kerja perawat dengan kepatuhan terhadap pelaksanaan Standar Prosedur Operasional (SPO) Pencegahan Pasien Jatuh di Rumah Sakit X Surabaya tahun 2016. Hasil penelitian ini sesuai dengan Handayani, Meliana (2014) yaitutidak ada hubungan antara variabel masa kerja dengan kepatuhan perawat dalam 
melaksanakan pedoman patient safety. Hikmah (2008) mendukung hasil tersebut dengan mengatakan bahwa tidak ada hubungan antara masa kerja dengan persepsi perawat terhadap patient safety. Hasil penelitian ini juga didukung oleh Anugrahini (2010) yang menemukan bahwa ada hubungan yang bermakna antara variabel masa kerja dengan kepatuhan perawat pelaksana dalam melaksanakan program patient safety.

Penelitian ini menunjukkan bahwasemakin tinggi motivasi maka semakin tinggi pula kepatuhan perawat dalam melaksanakan SPO Pencegahan Pasien Jatuh. Berdasarkan hasil tabulasi silang bahwa terdapat hubungan signifikan antara motivasi perawat dengan kepatuhan terhadap pelaksanaan Standar Prosedur Operasional (SPO) Pencegahan Pasien Jatuh di Rumah Sakit X Surabaya tahun 2016. Hal ini sesuai dengan Suyanto (2009) yaitu motivasi kerja akan berdampak pada kinerja perawat yang akan ditampilkan. Hasil dari penelitian sebelumnya menjelaskan bahwa perawat dengan motivasi yang tinggi akan mendukung sikap perawat dalam menerapkan program keselamatan pasien (Ariayani, 2009).

\section{SIMPULAN DN SARAN}

Hasil penelitian terhadap 47 perawat, diketahui terdapat 26 perawat $(55,3 \%)$ yang kurang patuh dalam melaksanakan Standar Prosedur Operasional (SPO) Pencegahan Pasien Jatuh di Rumah Sakit X Surabaya. Mayoritas usia responden yaitu 47 perawat di Rumah Sakit X Surabaya termasuk dalam kategori dewasa muda sebanyak 43 orang (91,5\%). Berdasarkan jenis kelamin, perawat perempuan lebih mendominasi sebanyak 37 perawat $(78,7 \%)$ dibandingkan laki-laki. Sebagian besar pendidikan dari 47 perawat adalah D3 sebanyak 37 orang $(78,7 \%)$. Kemudian, kategori lama masa kerja dari 47 perawat adalah tinggi sebanyak 24 perawat $(51,1 \%)$. Motivasi dari 47 perawat termasuk dalam kategori rendah yaitu sebanyak 32 perawat $(68,1 \%)$. Faktor demografis yaitu usia dan faktor motivasi memiliki hubungan signifikan dengan kepatuhan pelakasanaan SPO
Pencegahn Pasien Jatuh di Rumah Sakit X Surabaya.

\section{REFERENSI}

Anugrahini, Christina. (2010). Hubungan Faktor Individu dan Organisasi dengan Kepatuhan Perawat dalam Menerapkan Pedoman Patient Safety di RSAB Harapan Kita Jakarta.Tesis. Depok: Universitas Indonesia.

Ariayani. (2009). Analisis Pengetahuan dan Motivasi Perawat yang Mempengaruhi Sikap Mendukung Penerapan Program Patient Safety di Instalasi Perawatan Intensif RSUD Moewardi Surakarta tahun 2008.Tesis. Semarang: Universitas Diponegoro.

Depkes. (2006). Panduan Nasional Keselamatan Pasien Rumah Sakit (Patient Safety). Retrieved 12 14, 2015, from http://www.inapatsafetypersi.or.id/data/panduan.pdf

Handayani, Meliana. (2014). Hubungan Karakteristik Perawat dan Kepemimpinan dengan Kepatuhan Perawat dalam Melaksanakan Pedoman Patient Safety di Ruang Inap Rumah Sakit Stella Maris Makassar.Skripsi. Makssar: Universitas Hasanuddin. Handoko, H. (2007). Mengukur Kepuasan Kerja. Jakarta: PT. Bumi Aksara.

Hikmah, S. (2008). Persepsi Staf mengenai "Patient Safety" di Instalasi Rawat Darurat (IRD) RSUP Fatmawati.Skripsi. Depok: Universitas Indonesia.

Niven, N. (2008). Psikologi Kesehatan : Pengantar Untuk Perawat Dan Profesional. Jakarta: EGC.

Peraturan Menteri Kesehatan Republik Indonesia nomor 1691 tahun 2011 tentang Keselamatan Pasien Rumah Sakit.

Ranupendoyo dan Saud. (2005) Manajemen Personalia, Edisi 4. Yogyakarta: Pustaka Binawan Presindo FEUGM. 
Robbins, S. (2006). Perilaku Organisasi Edisi kesepuluh. Jakarta: PT. Indeks Kelompok Gramedia.

Rollinson, D., Kish. (2010). Care Concept in Advanced Nursing. St. Louis. Mosby A Harcourt Helath Science Commpany.

Sopiah. (2008). Perilaku Organisasi. Yogyakarta: Andi

Stanley, M and Beare, P. G. (2006). Buku Ajar Keperawatan Gerontik. Jakarta: EGC.

Suyanto. (2009). Mengenal Kepemimpinan dan Manajemen Keperawatan. Yogyakarta: Mitra Cendikia Press.

Tinetti ME, Speechley M, Ginter SF. (1988). Risk factors for falls among elderly persons living in the community. $\mathrm{N}$ Engl $\mathrm{J}$ Med;319(26):1701-7. BIBLIOGRAPHY $\backslash 1033$

Undang-Undang Republik Indonesia Nomor 1 tahun 1974 Tentang Pernikahan

Undang-undang No. 20 tahun 2003 tentang

Sistem Pendidikan Nasional 
JURNAL ILMIAH KESEHATAN MEDIAHUSADA ｜ VOLUME 06/NOMOR 02/OKTOBER 2017 